\title{
SPRAY DEPOSIT VARIABILITY IN NEW ZEALAND WINEGRAPE CANOPIES AND IMPLICATIONS FOR AGRICHEMICAL APPLICATION PRACTICES
}

\author{
D.W. MANKTELOW ${ }^{1}$ and J-P. PRAAT ${ }^{2}$ \\ ${ }^{1}$ HortResearch, Hawke's Bay Research Centre, Private Bag 1401, Havelock North \\ ${ }^{2}$ Lincoln Ventures Ltd, Ruakura Research Centre, Private Bag 3062, Hamilton
}

\begin{abstract}
Introduction of new grape sprayers and vineyard planting systems in New Zealand has led to uncertainty over agrichemical application rate requirements in different canopies. A 1998 survey of spray application practices on 15 Hawke's Bay vineyards found up to a sixfold difference between vineyards in the rates of sulphur fungicides applied to fully developed canopies. Follow-up work in 1999-00 found that two-fold within-canopy spray deposit variations were common. Earlier work indicated that deposits on upper surfaces of leaves can be up to three times greater than on lower surfaces. Methods for reducing deposit variations and for more precise definition of agrichemical application rate requirements are discussed.
\end{abstract}

Keywords: wine grape, spray application, agrichemical rate, agrichemical deposit, agrichemical label.

\section{INTRODUCTION}

The majority of New Zealand winegrape canopies are trained using some form of vertical shoot positioning (VSP). These canopies are usually mechanically trimmed through the season to form a box section that will vary in height and density with seasonal growth stage, site vigour, cultivar and vineyard canopy management practices (Smart and Robinson 1991). Despite the outward uniformity of many winegrape canopies, large between-canopy variations can exist due to differences in canopy wall height and leaf or bunch density. Such variations may have a major influence on size and uniformity of spray deposits.

The area planted in vineyards has increased from ca 5,000 ha in 1990 to ca 12,000 ha in 1999 (Anon. 1999). A majority of the blocks in the ground in 1990 can be described as having a "standard" cane or spur pruned VSP canopy, planted on $3 \mathrm{~m}$ row spacings (traditionally 10 feet), with typical trimmed wall dimensions of $1.3-1.5 \mathrm{~m}$ tall by $0.3-0.5 \mathrm{~m}$ wide. The trimmed wall dimensions of plantings since 1990 have not changed greatly. However, there has been a trend to reduce row widths on low vigour sites to between 1.8 and $2.7 \mathrm{~m}$ and the canopies on low vigour sites tend to be far less dense than those found on more traditional production areas.

In the 1980s most vineyard spraying was done using either axial fan air blast sprayers or non-air assisted booms fitted with hydraulic nozzles or guns. In both cases sprays were typically applied to runoff using water volumes of 900-1,500 litres/ha. The last 10 years has seen the introduction and widespread adoption of a number of new and improved air assisted sprayers. It was estimated that over $40 \%$ of the winegrape area in New Zealand in 1999-00 was sprayed using modern over-row air assisted sprayers capable of applying spray volumes anywhere between 200 and 1,000 litres/ha (Small 2000).

All agrichemical labels give at least one product rate per 100 litres of "dilute" spray mix (i.e. for "high volume" spray applications to wet the canopy to the point of runoff). However, some include potentially ambiguous minimum water volume or product per hectare recommendations and most fail to account for differences between spray application systems, canopies or degree of pest or disease risk. For example, of 34 
fungicides listed in N.Z. Agrichemical Manual for grapes (Anon. 1998), 16 included recommended minimum water volume or product quantities per hectare. However, the spray application volumes thus recommended, or implied, were not consistent and ranged from 650 to 2,000 litres/ha, with eight products having recommended volumes of 1,000 litres/ha. Agrichemical application rate or spray volume recommendations based on ground area are meaningless unless they are made with reference to a target canopy type and row spacing. For example, a canopy on a $3.0 \mathrm{~m}$ row spacing would have ca $3.3 \mathrm{~km}$ of row per hectare, whereas an otherwise identical canopy on a $1.8 \mathrm{~m}$ row spacing would have ca $5.5 \mathrm{~km}$ of row per hectare. The $1.8 \mathrm{~m}$ row spacing would have $66 \%$ more canopy per hectare, which should require $66 \%$ more spray to achieve deposits equivalent to the $3.0 \mathrm{~m}$ spacing.

This paper describes variations in spraying practices used by Hawke's Bay grape growers and trends in within-canopy spray deposit variations observed in their canopies.

\section{MATERIALS AND METHODS}

Work from three studies is reported and, although all had some canopies and sprayers in common, each should be examined independently.

\section{Variations in spraying techniques in grapes in Hawke's Bay}

Thirteen Hawke's Bay vineyards involved in a Technology New Zealand funded TBG project on Integrated Winegrape production were visited over the 1998 harvest period to assess their sprayers and spraying practices (Table 1). The calibration of each sprayer was checked (not adjusted) and spray deposits were examined on water sensitive papers placed on fixed target spray poles at five heights within the canopy. The property spray diary was examined and, as all properties used sulphur for powdery mildew control, full canopy sulphur application rates used on each property were compared. Canopy height, distance from ground to canopy bottom and canopy width were also recorded.

\section{Leaf deposit variability between canopy zones within vines}

Fourteen spray deposit tests, each involving different sprayer types or configurations, were conducted on commercial vineyards in the 1999-2000 season to assess deposit variability within grape canopies. Ten different canopies were involved in the tests, with one canopy receiving five separate tests. The following seven different types of sprayer were tested: Silvan GII (5 tests), Holder Crossflow ( 2 tests), Croplands Turbocol (1 test), Croplands airshear (2 tests), Micronaire (1 test), high volume guns with no air assistance ( 2 tests) and a hand gun (1 test). All but one of the tests was conducted on fully developed VSP canopies between January and March 2000. One test was conducted in November, when the canopy had reached its trimmed height, but the leaf canopy was not fully developed. Spray volumes applied ranged from 300-1,000 litres/ha, but in each case the sprayer was set-up to treat the full canopy as evenly as possible. Hexagran Brilliant Blue FCF Supra food dye (Bayer) was applied as a tracer at ca $1 \mathrm{~kg} / \mathrm{ha}$. After spray had dried three replicate samples of five leaves were collected from the inner and outer canopy from each of three canopy height zones (Table 2). Dye deposits were washed off the leaf samples using $50 \mathrm{ml}$ of distilled water and dye concentration was assessed from absorbance measurements at $630 \mathrm{~nm}$. Sample leaf areas were measured using an electronic leaf area meter (Licor) and spray deposits were estimated per square centimetre of projected leaf area. Deposits from each canopy were expressed as the percentage of the highest zonal deposit observed for that canopy and zonal deposit trends between the different canopies were compared using analysis of variance of arcsine transformed data.

\section{Deposit variability between leaf surfaces}

Fluorescent tracer (YFP, Department of Primary Industries, Loxton, South Australia) deposits on leaves were assessed in 1995 and 1996. The 1995 study involved seven different makes of sprayer which all treated a dense, machine pruned canopy with application volumes ranging from 220-900 litres/ha, plus a single sprayer treatment of a modern VSP canopy (Table 3). The 1996 study involved three makes of sprayer which all treated a modern VSP canopy with application volumes ranging 
from 250-500 litres/ha (Table 3). In each case, 25 leaf samples were taken from each of the inner and outer canopy zones in the bunchline area or the unplucked canopy above this. Leaf top and bottom surfaces were scored separately for percentage area covered with spray, using six arbitrary coverage rankings $(0,5,25,50,75$ or 100\%). Top and bottom surface coverage was expressed as the mean of the coverage scores from 25 leaves from each zone. Data from the four sample zones were combined to produce average estimates of coverage on top and bottom leaf surfaces for each sprayer examined.

TABLE 1: Summary of spray application volumes, travel speeds, work rates and full canopy sulphur application rates ${ }^{1}$ on thirteen Hawke's Bay vineyards in 1998.

\begin{tabular}{|c|c|c|c|c|c|c|c|}
\hline \multicolumn{2}{|r|}{$\begin{array}{l}\text { Property number and } \\
\text { type of sprayer }\end{array}$} & $\begin{array}{l}\text { Appl. } \\
\text { Vol. } \\
\text { (litres/ha) }\end{array}$ & $\begin{array}{l}\text { Speed } \\
(\mathrm{km} / \mathrm{hr})\end{array}$ & $\begin{array}{l}\text { Work } \\
\text { rate } \\
\text { (ha/hr) }\end{array}$ & $\begin{array}{l}\text { Sulpl } \\
\text { rates (a } \\
\mathrm{kg} / \mathrm{ha}\end{array}$ & $\begin{array}{l}\text { ur appl } \\
\text { ctive in } \\
\mathrm{kg} / \mathrm{km} \\
\text { row }\end{array}$ & $\begin{array}{l}\text { ication } \\
\text { gredient) } \\
{\mathrm{g} / \mathrm{m}^{2}}^{2} \\
\text { canopy }\end{array}$ \\
\hline & $\begin{array}{l}\text { Vertical wet boom: two row, } \\
\text { no air assistance }\end{array}$ & 1000 & 7.1 & 2.1 & 0.8 & 0.18 & 0.06 \\
\hline & Typhoon airblast: single row & 1000 & 7.7 & 1.6 & 1.1 & 0.32 & 0.10 \\
\hline & Typhoon airblast: single row & 1000 & 7.6 & 1.8 & 1.2 & 0.37 & 0.11 \\
\hline & $\begin{array}{l}\text { Massotti guns: single row no } \\
\text { air assistance }\end{array}$ & 1000 & 5.5 & 1.3 & 1.6 & 0.49 & 0.13 \\
\hline & $\begin{array}{l}\text { Croplands Turbocol: } \\
\text { two row vertical boom }\end{array}$ & 525 & 7.5 & 2.9 & 2.4 & 0.66 & 0.15 \\
\hline & $\begin{array}{l}\text { Croplands airshear: } \\
\text { two row, hand-type heads }\end{array}$ & 500 & 7.5 & 2.6 & 1.2 & 0.29 & 0.09 \\
\hline & $\begin{array}{l}\text { Silvan airshear: two row, } \\
\text { hand-type heads }\end{array}$ & 500 & 6.9 & 2.7 & 0.9 & 0.24 & 0.09 \\
\hline & Holder crossflow, two row & 480 & 7.4 & 2 & 0.7 & 0.12 & 0.06 \\
\hline 9. & Micronaire: single row & 400 & 7.1 & 1.7 & 2.4 & 0.72 & 0.23 \\
\hline & $\begin{array}{l}\text { Holder Crossflow + wet } \\
\text { boom: two row, boom on } \\
\text { outside with no air assistance }\end{array}$ & 400 & 7.9 & 3.4 & 1.6 & 0.49 & 0.16 \\
\hline & Croplands Turbocol: two & & & & & & \\
\hline & row vertical boom & 400 & 6.4 & 2.9 & 1.8 & 0.54 & 0.15 \\
\hline & Micronaire: two row & 260 & 9.3 & 4.1 & 1.6 & 0.49 & 0.17 \\
\hline 13. & Hardi ducted air: two row & 175 & 6.2 & 3 & 1.4 & 0.35 & 0.16 \\
\hline & $\operatorname{Max} / \min ^{3}$ & 5.7 & 1.7 & 3.2 & 3.4 & 6.0 & 3.8 \\
\hline
\end{tabular}

${ }^{1}$ Calculated from chemical application rates stated in grower spray diaries for full canopy sprays.

${ }^{2}$ Expressed as grams of sulphur active ingredient per square metre of canopy wall area.

${ }^{3}$ Maximum value divided by the minimum value.

\section{RESULTS}

\section{Variations in spraying techniques in grapes in Hawke's Bay}

The sprayers examined (Table 1) can be regarded as a fairly typical representation of vineyard spraying practices in Hawke's Bay. Most of the sprayers were found to be performing to within $10 \%$ of their target travel speeds and application volumes. However two sprayers were more than $20 \%$ off-target as a result of easily corrected calibration problems. Spray deposits on water sensitive papers indicated that runoff occurred in most parts of the canopy with application volumes of around 1,000 litres/ ha. However, coverage from the airblast sprayers tended to be less even than that from the sprayers with no air assistance. Coverage from the two sprayers that applied less than 300 litres/ha was the most uneven and was considered more sparse than desirable 
for full canopy applications. Coverage from the sprayers that were operated in the 400-600 litres/ha range was remarkably variable, with the best and worst coverage observed with small and large droplets respectively. There was a large variation in spraying work rates between properties, due partly to differences in travel speeds, but mainly to single versus two row spraying. Sulphur application rates were remarkably variable, with a ca six-fold difference observed between vineyards (Table 1).

\section{Leaf deposit variability between canopy zones within vines}

Spray deposits on inner leaves were lower than those on outer leaves at all three height zones and spray deposits were highest around the bunchline area of all of the canopies examined (Table 2).

\section{TABLE 2: Trends in leaf spray deposit variability between grapevine canopy zones.}

Leaf sample zone ${ }^{1}$

Bunch line (leaf plucked)

Bunch line (leaf plucked)

Unplucked canopy to post tops

Unplucked canopy to post tops

Unplucked canopy above post tops

Unplucked canopy above post tops
Inner or outer

leaves selected

from zone
Deposit in zone as a percentage of the maximum deposit ${ }^{2}$

${ }^{1}$ Each height zone was approximately $0.5 \mathrm{~m}$ tall.

${ }^{2}$ Back-transformed data averaged from 13 separate tests, numbers followed by the same letter were not statistically different $(\mathrm{P}<0.05)$.

\section{Deposit variability between leaf surfaces}

Top and bottom surfaces of inner canopy leaves received on average only $68 \%$ of the deposits achieved on the outer canopy (data not presented) and was consistent with the trends shown in Table 2. There was a strong trend across all zones for lower leaf surfaces to receive less spray than the upper surfaces (Table 3). Sprayers with a vertical boom configuration (with or without air assistance) tended to be most consistent across the different canopy zones, but tended to show a greater surface to surface deposit variation than the other types of sprayer examined. Sprayers with radiating plume emissions tended to have the greatest variation in surface to surface spray deposits between zones.

\section{DISCUSSION}

Given the often large differences in leaf density between different parts of a grape canopy, it is unlikely that any sprayer, or sprayer setup, will be able to produce uniform spray deposits throughout a fully developed canopy. The higher deposits observed in the canopy bunchline are not necessarily undesirable, but more attention to directing spray into the upper canopy regions may be required when this is the primary target of a spray application. The deposit tests reported in this paper were all conducted after leaf plucking had commenced and it is likely that more even deposits could be achieved at earlier developmental stages.

Definition of agrichemical rate recommendations on the basis of the quantity of chemical required per 100 litres of dilute spray mixture (sprayed to the point of runoff) arguably remains the most consistent and unambiguous standard from which growers can interpret the chemical application rate requirements for their vineyards. However, growers still lack methods for adjusting spray volume, and hence chemical application rates, to suit different canopies as they develop and are managed through the season. 
TABLE 3: Spray coverage on grape leaf top and bottom surfaces from 11 different tests with eight types of sprayer. Deposit data was averaged from four canopy sample zones and ranked on differences in coverage between top and bottom surfaces.

\begin{tabular}{|c|c|c|c|c|c|}
\hline \multirow[t]{2}{*}{ No. } & \multirow{2}{*}{$\begin{array}{l}\text { Sprayer } \\
\text { type }\end{array}$} & \multirow{2}{*}{$\begin{array}{c}\text { Spray } \\
\text { output form }\end{array}$} & \multicolumn{3}{|c|}{ Mean $\%$ area covered with spray } \\
\hline & & & Top & Bottom & Bottom/Top \\
\hline 1 & Guns - no air & Vertical boom $^{2}$ & 80 & 27 & $33 \%$ \\
\hline 2 & Guns + Crossflow ${ }^{1}$ & Vertical boom & 77 & 28 & $37 \%$ \\
\hline 3 & Crossflow & Vertical boom & 83 & 34 & $41 \%$ \\
\hline 4 & Crossflow & Vertical boom & 75 & 32 & $42 \%$ \\
\hline 5 & Guns + Crossflow ${ }^{1}$ & Vertical boom & 89 & 39 & $44 \%$ \\
\hline 6 & Hydra & Directed axial fan ${ }^{3}$ & 56 & 30 & $52 \%$ \\
\hline 7 & Hand-type air shear & Radiating plume $^{4}$ & 58 & 37 & $64 \%$ \\
\hline 8 & Air shear & Vertical boom & 63 & 42 & $66 \%$ \\
\hline 9 & Micronaire & Directed axial fan & 75 & 51 & $68 \%$ \\
\hline 10 & Hand-type air shear & Radiating plume & 45 & 33 & $73 \%$ \\
\hline \multirow[t]{2}{*}{11} & Orchard airblast & Radiating plume & 44 & 48 & $109 \%$ \\
\hline & & Averages & 68 & 36 & $57 \%$ \\
\hline
\end{tabular}

${ }^{1}$ An over row sprayer with air assistance on one side and an un-air assisted boom on the other.

${ }^{2}$ Nozzles separated vertically, each directly targeting a discrete canopy height band. ${ }^{3}$ Small axial fans blowing spray directly onto the canopy.

${ }^{4}$ Nozzle and air outputs directed horizontally into the bunchline through to ca $45^{\circ}$ upwards into the upper canopy.

Problems with inconsistent industry interpretation of rate requirements have been recognised by the NZ winegrape industry and this was the subject of an address at the 1997 Romo-Bragatto conference (Miller 1997). Chemical application rate adjustments, which will result in equivalent chemical doses on different canopies or canopy growth stages, can be achieved by calculating application rates per metre or kilometre of sprayed canopy, with allowances made for canopy height, density and/ or volume. The Unit Canopy Row (Furness and Magrey 2000) and Fruitwall Technique (Koch 1992) are two proposed methods for defining chemical application rate requirements. However, these include some unrefined assumptions as to the base dilute spray volumes required to achieve coverage to the point of runoff in different types of grape canopy. Use of the least possible agrichemical to achieve effective pest and disease control requires firstly, knowledge of the minimum effective chemical dose (Warren et al. 1999) and secondly, an understanding of likely deposit variations through a canopy with training system, growth stage and spray application method. Rational adjustments are also required to account for the relative efficiency of different spray application techniques (e.g. concentrate versus dilute application and air assisted versus non-air assisted sprayers) and for different pest or disease pressures.

\section{CONCLUSIONS}

Improved targeting of spray onto grape canopies requires some knowledge of deposit distribution patterns through different types of canopies and from different spray application systems. Rationalising agrichemical use will require integration of data on the chemical dose rates required to control the target pest or disease, the area within the canopy that this dose must be achieved and a system by which the user can interpret chemical label rates to best relate to their particular canopy and sprayer combination. 


\section{ACKNOWLEDGEMENTS}

Silvan New Zealand Ltd, for permission to publish data collected during the evaluation of their sprayers. The growers involved in the Hawke's Bay IWP Technology New Zealand funded TBG project for enabling us to work with them and to present some of the results from that work.

\section{REFERENCES}

Anon. 1999. Horticulture facts and figures 1999. The Horticulture and Food Research Institute of New Zealand Ltd, Palmerston North, New Zealand. 25 pp.

Furness, G.O., Magarey, P.A., 2000. Unit canopy row calibration and a new pesticide label format to improve dose consistency on different canopy sizes with spray application to fruit trees and vines in Australia. Aspects of Applied Biology, Pesticide Application 57: 309-312.

Koch, H., 1992. Technically determined and stochastic process during spraying and their implications on dosage and distribution. Gesunde Pflanzen $44 \mathrm{Jahrg}$., Heft 10: 350-360.

Miller, P., 1997. Applying "vine-row-volume" principles to rate selection and spray machinery operations. The Bragato address, Romeo-Bragato conference, Gisborne, August 1997.

O’Connor, 1998. New Zealand Agrichemical Manual. Novachem Services Ltd, RD4, Palmerston North, New Zealand. 452 pp.

Smart, R. and Robinson, M., 1991. Sunlight into Wine: A handbook for winegrape canopy management. Winetitles, Adelaide. $88 \mathrm{pp}$.

Warren, M.A., Riches, D.A. and Murphy, K.L., 1999. Dose-response curves and bioassays used for predicting the efficacy of sulphur sprays for powdery mildew (Uncinula necator) on grapevines. Proc. APPS 12th Biennial Conf., Canberra: 215. 